\title{
Compositional trends of spinel and mica in alkali minettes, southern Alberta, Canada
}

\author{
B.A. Kjarsgaard ${ }^{1}$ \\ 1. Geological Survey of Canada, 601 Booth Street, Ottawa, Ontario, Canada K1A 0E8
}

Strongly potassic igneous rocks exposed in the Milk River (Sweet Grass) area of southern Alberta, Canada outcrop as hypabyssal intrusive rocks (dykes, plugs) as well as extrusive rocks (fig. 1). Whole-rock geochemistry, petrographic studies and mineral chemistry demonstrate that the Sweet Grass rocks are minette (Kjarsgaard, 1994). These minettes demarcate the northern extent of the Montana alkaline province. A Rb-Sr phlogopite/whole-rock isochron age of $50.3 \pm 0.5 \mathrm{Ma}$ reported by Davis and Kjarsgaard (1994) confirms an Eocene emplacement age for the Sweet Grass minettes in southern Alberta. This age is synchronous with the peak of magmatic activity occurring in the Montana alkaline province (Missouri Breaks, Eagle Buttes, Sweet Grass Hills and the Bearpaw and Highwood Mountains) at 49 - 55 Ma (Davis and Kjarsgaard, 1994).

The Sweet Grass rocks in Alberta are subdivided into four types of minette: 1.) alkali olivine minette; 2.) phlogopite minette; 3.) alkali minette, and; 4.) peralkaline minette. Coarse grained spinelbearing xenoliths (clinopyroxenite, phlogopite clinopyroxenite, and glimmerite) occur in minette types $1-3$. The mineralogy is similar to the host; these xenoliths are considered of cognate origin. In all minettes, phlogopite and clinopyroxene phenocrysts are strongly zoned, showing normal, reverse and oscillatory zoning. In contrast, minerals in the cognate xenoliths show minor or no compositional zoning. In mafic minettes, glomerophyric clusters comprised of $\mathrm{Cr}$-spinel, olivine and phlogopite are common.

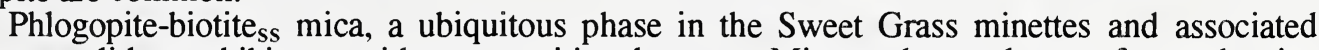
cognate xenoliths, exhibits a wide compositional range. Microprobe analyses of zoned mica phenocrysts (core to rim) and homogeneous groundmass crystals from minette, mica from cognate xenoliths, and mica from glomerophyric clusters are illustrated in figure $2 \mathrm{~A}, \mathrm{~B}$. The salient points to be observed on these two diagrams are: 1) zoning trends show increasing $\mathrm{FeO}_{\text {total }}$ and $\mathrm{TiO}_{2}$ at constant to decreasing $\mathrm{Al}_{2} \mathrm{O}_{3} ; 2$ ) compositions of mica from cognate xenoliths overlap those from the core and middle of zoned phenocrysts, although $\mathrm{Al}_{2} \mathrm{O}_{3}$ contents are slightly higher in mica from cognate xenoliths; and; 3 ) most, but not all compositions fall in the known range for micas from minettes (c.f. Mitchell and Bergman, 1991). The trend of decreasing $\mathrm{Al}_{2} \mathrm{O}_{3}$ in the Sweet Grass micas is suggested here to be typical of alkaline and peralkaline minettes; it is also observed, but not well developed in other highly alkaline minettes (e.g. Bohemian alkali minettes; Mitchell and Bergman, 1991).

Compositions of spinel in minettes and cognate xenoliths are bimodal: early, primitive high pressure liquidus $\mathrm{Cr}$ - and $\mathrm{Mg}$-rich spinel in glimmerite xenoliths and glomerophyric clusters in minette, and late, fractionated mid to low pressure liquidus $\mathrm{Ti}$ - and $\mathrm{Fe}$-rich spinel in clinopyroxenite xenoliths and the minette groundmass. The variation in spinel chemistry is displayed utilizing a plot of $M g \#$ versus $\mathrm{Ti} / \mathrm{Ti}+\mathrm{Cr}+\mathrm{Al}$ (the front face of the reduced spinel prism; Mitchell, 1986). Figure 3 illustrates the compositional trend of $\mathrm{Cr}$-, and $\mathrm{Ti}$ - and Fe-rich spinels from the Sweet Grass data set, and for comparison, magmatic spinel trends observed in kimberlite, lamproite, and a variety of ultrabasic rock types (Mitchell, 1986). The Sweet Grass minette spinel trend is similar to magmatic spinel trend 2. The compositional gap observed at intermediate $M g \#$ (fig. 3) suggests that spinel is not a liquidus phase throughout the crystallization history.

Major element chemistry of Cr-spinels ( $>50 \mathrm{wt} \% \mathrm{Cr}_{2} \mathrm{O}_{3}$ ) from the Sweet Grass minettes are shown on $\mathrm{MgO}-\mathrm{Cr}_{2} \mathrm{O}_{3}$ and $\mathrm{TiO} 2-\mathrm{Cr}_{2} \mathrm{O}_{3}$ bivariate plots (fig. 4A, B), and compared with $\mathrm{Cr}$-spinel data from diamond inclusions and kimberlite- and lamproite-derived spinels. Note that a subset of the Sweet Grass Cr-spinels fall into the diamond inclusion field in $\mathrm{MgO}-\mathrm{Cr}_{2} \mathrm{O}_{3}$ space, but are separated in $\mathrm{TiO}_{2}-\mathrm{Cr}_{2} \mathrm{O}_{3}$ space. However, the minette-derived $\mathrm{Cr}$-spinels fall into the field of $\mathrm{Cr}$-spinels unique to kimberlite and lamproite on a $\mathrm{TiO} 2-\mathrm{Cr}_{2} \mathrm{O}_{3}$ discriminant diagram.

Trace element chemistry of $\mathrm{Cr}$-spinels from the Sweet Grass minettes (Ni and $\mathrm{Zn}$, determined by PIXE and EMP) is illustrated in figure 5. Note the overlap of the Sweet Grass Cr-spinel data with lamproite phenocryst $\mathrm{Cr}$-spinels, diamond inclusion $\mathrm{Cr}$-spinels, and $\mathrm{Cr}$-spinel xenocrysts from kimberlite and orangeite. 
The Sweet Grass minette Cr-spinel data illustrate the complexity of utilizing spinel chemistry alone in diamond exploration programs. Utilizing existing major or trace element discriminant diagrams, the Sweet Grass Cr-spinels would be interpreted as being derived from lamproite or kimberlite, whereas they are in fact minette-derived.

\section{References}

Davis, W.J., and Kjarsgaard, B. A., 1994, A Rb-Sr phlogopite - whole rock isochron age for olivine minette from the Milk River area, southern Alberta: Geological Survey of Canada, Current Research, 1994-F, p. 11 - 14.

Fipke, C., 1994, Significance of chromite, ilmenite, G5 Mg-almandine garnet, zircon and tourmaline in heavy mineral detection of diamond-bearing lamproite: In Proc. 5IKC, Brazil, v. 2, Diamonds: Characterization, Genesis and Exploration, Meyer H.O.A. and Leonardos O.H. (ed.); CPRM Spec. Pub. 1B, p. 215 - 235.

Griffin, W.L., Ryan, C.J., Gurney, J.J., Sobolev, NV., and Win, T.T., 1994, Chromite macrocrysts in kimberlites and lamproites: geochemistry and origin. In Proc. 5IKC, Brazil, v. 1, Kimberlites, related rocks and mantle xenoliths, Meyer H.O.A. and Leonardos O.H. (ed.); CPRM Spec. Pub. 1A, p. 366 - 377.

Kjarsgaard, B.A., 1994, Potassic magmatism in the Milk River area, southern Alberta: petrology and economic potential: In Geological Survey of Canada, Current Research, 1994-B, p. 59 - 68.

Mitchell, R.H., 1986, Kimberlites: Plenum Press, New York, 442 p.

Mitchell, R.H., and Bergman, S.C., 1991, Petrology of lamproites: Plenum Press, New York, 447 p.

Moore, R.O., and Gurney, J.J., 1989, In Fipke, C., The development of advanced technology to distinguish between diamondiferous and barren diatremes: Geological Survey of Canada, Open File 2124 , v. 1 , p. 1 - 90.

\section{Figure Captions}

Figure 1. Location of the Sweet Grass minettes in southern Alberta, Canada.

Figure 2. Microprobe analyses of mica from the Sweet Grass minettes: A) $\mathrm{Al}_{2} \mathrm{O}_{3}$ versus $\mathrm{TiO}_{2}$;

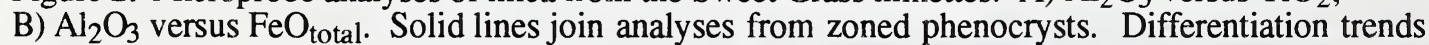
(after Mitchell, 1986; Mitchell and Bergman, 1991): $\mathrm{M}=$ minette; WK = West Kimberley; $\mathrm{C}=$ Chelima; $\mathrm{S}=$ Sisimiut; $\mathrm{LH}_{\mathrm{gm}}=$ Leucite Hills groundmass; $\mathrm{LH}_{\mathrm{Al}}=$ Leucite Hills aluminous biotite .

Figure 3. The front face of the reduced spinel prism, comparing the compositional trend of magmatic spinels from the Sweet Grass minettes (this study) with magmatic spinel trend 1 and 2 (Mitchell, 1986).

Figure 4. Microprobe analyses of $\mathrm{Cr}$-spinel from the Sweet Grass minettes: $\mathrm{A}$. $\mathrm{MgO}$ versus $\mathrm{Cr}_{2} \mathrm{O}_{3}$; B) $\mathrm{TiO}_{2}$ versus $\mathrm{Cr}_{2} \mathrm{O}_{3}$ spinel discrimination plot after Fipke (1994), solid lines separate: diamond inclusion spinels (D.I.) versus spinels unique to kimberlite and lamproite $(K+L)$ versus spinels from the overlap field. Approximately half the Sweet Grass minette Cr-spinels fall into the field of spinels suggested to be unique to kimberlite or lamproite.

Figure 5. Comparison of $\mathrm{Zn}$ versus Ni concentration for Sweet Grass minette Cr-spinels (filled diamonds) with fields for Cr-spinel from: diamond inclusions (D.I.): lamproites; kimberlite and orangeite (fields after Griffin et al., 1994). Note that most Sweet Grass minette $\mathrm{Cr}$-spinels fall in the lamproite phenocryst field and/or the kimberlite plus orangeite xenocryst field. 


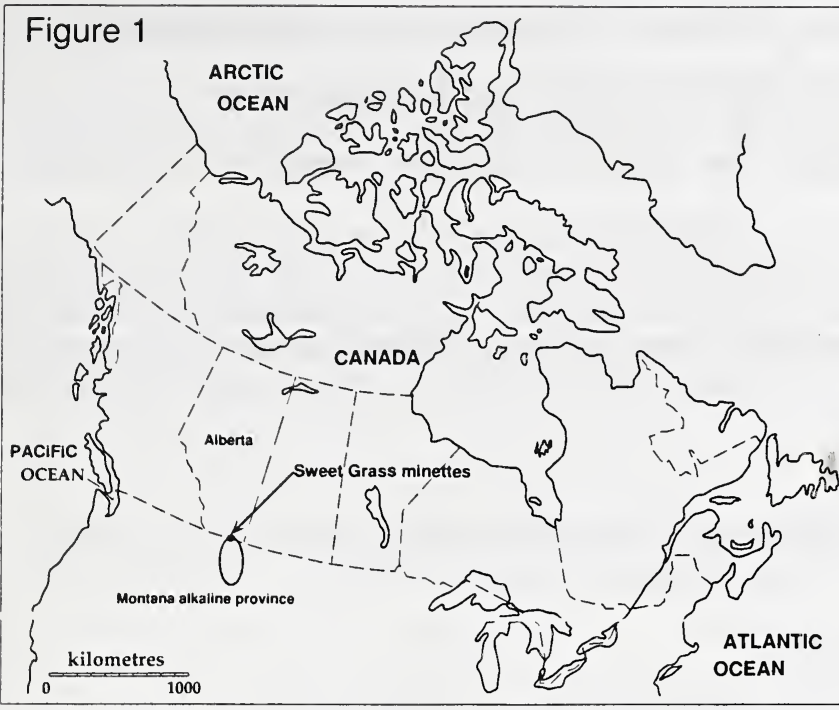

Figure 3

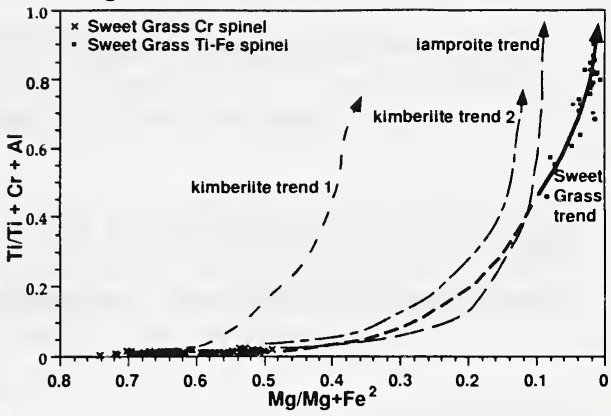

Figure 4A

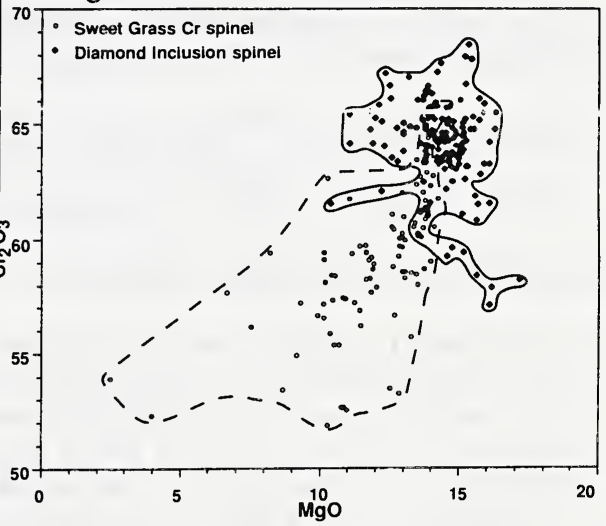

M.
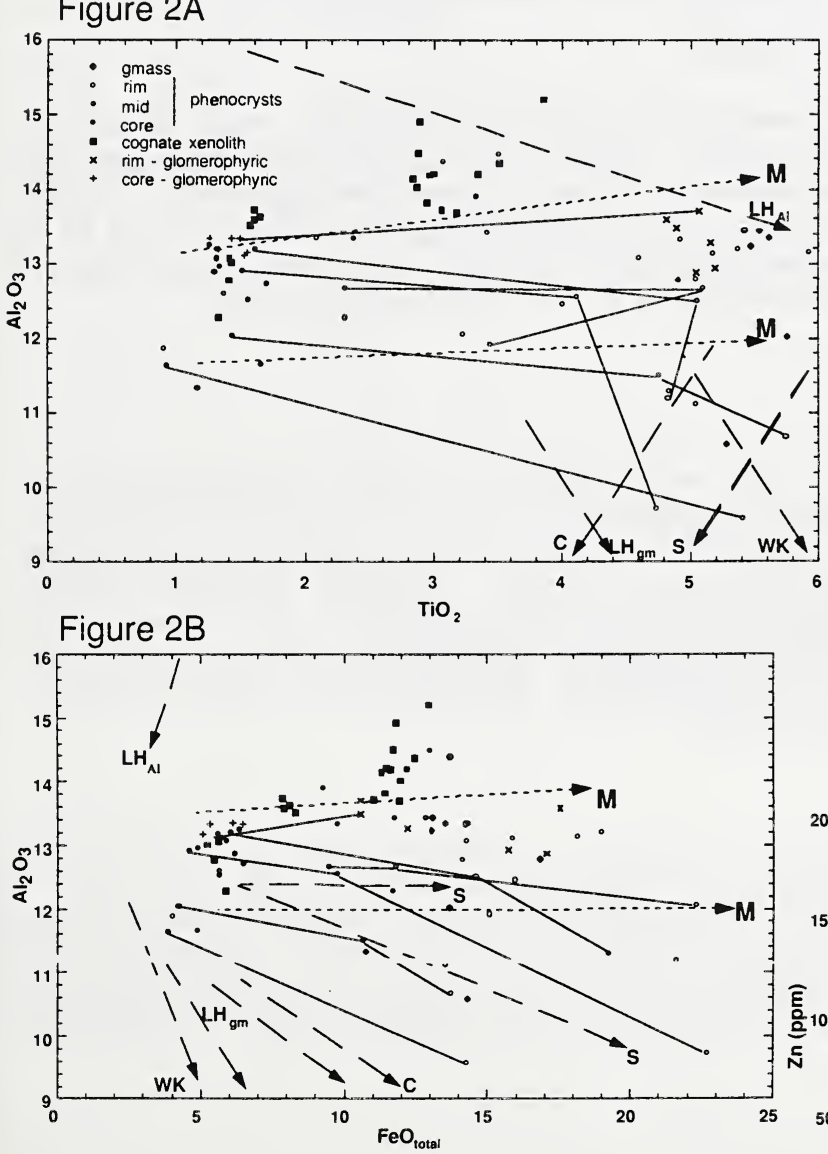

Figure 5
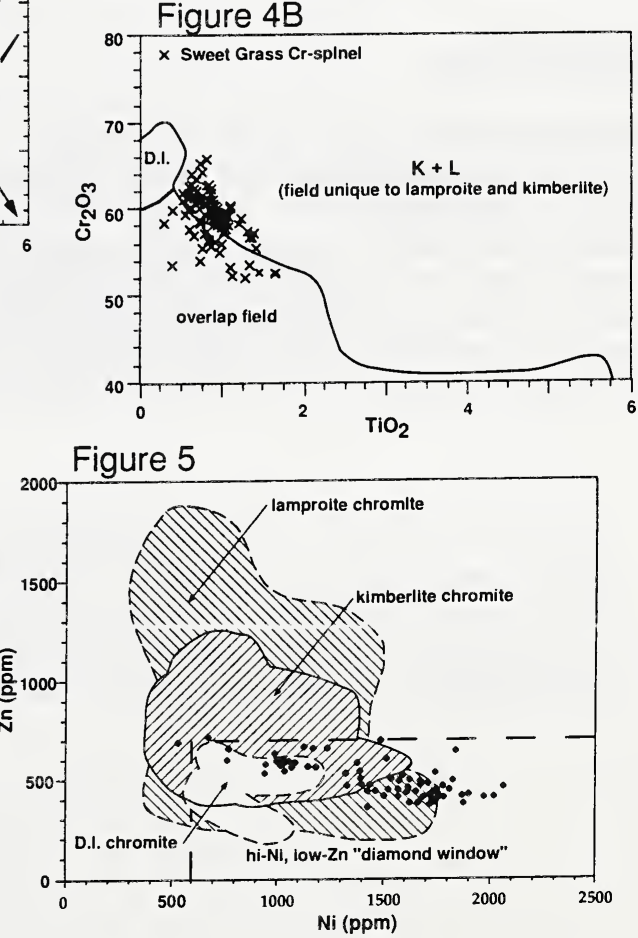